\title{
Development challenges in the age of climate change: the case of Sidama*
}

\author{
By Seyoum Yunkura Hameso ${ }^{\dagger}$
}

\begin{abstract}
Today, developing countries face distinctive challenges of development such as to poverty reduction, growth and economic development. The growing concern with climate change presents additional challenges and opportunities to these countries. The paper explores development possibilities/challenges in the age of climate change on the basis of selected review of the literature on mainstreaming climate change to development. The themes under discussion relate to on-going empirical research on vulnerability and adaptions to climate change in Ethiopia, the case of smallholder farmers in Sidama.
\end{abstract}

\footnotetext{
* Paper presented at the Workshop on the Economy of Southern Ethiopia, organized by the Ethiopian Economics Association, its Chapter at Hawassa University, Department of Economics, held on 1 March 2012.

${ }^{\dagger}$ University of East London and Hawassa University. Author can be reached at seyoum01@gmail.com
} 


\title{
Outline
}

1. Introduction

2. Background

3. Development agendas of developing economies

4. A history of environmental concerns on development

5. Development challenges in the age of climate change

5.1. The case of Ethiopia

5.2. The case of Sidama

5.3. Development constraints and opportunities

6. Conclusions

References

\section{Introduction}

This brief paper addresses some challenges of development in the age of climate change. It starts with an exploration of the background to the problem of development and climate change, followed by a brief history of environmental concerns and sustainable development. Then it outlines key post-WWII development agendas and development challenges facing developing economies in the age of climate change, taking the case of Sidama Zone. The paper concludes with tentative recommendations.

\section{Background}

\begin{abstract}
Climate change is one of the most complex challenges of our young century. No country is immune. No country alone can take on the interconnected challenges posed by climate change, including controversial political decisions, daunting technological change, and far-reaching global consequences.

As the planet warms, rainfall patterns shift and extreme events such as droughts, floods, and forest fires become more frequent. Millions in densely populated coastal areas and in island nations will lose their homes as the sea level rises. Poor people in Africa, Asia, and elsewhere face prospects of tragic crop failures; reduced agricultural productivity; and increased hunger, malnutrition, and disease.

World Bank, 2010, p. xiii
\end{abstract}

The quote above is important because it captures the sense of urgency in dealing with climate change. A growing body literature recognises climate change as the most urgent challenge, presenting a unique challenge for economies and economics (Stern, 2007; Giddens, 2009; see also the concept map in Appendix).

Some scholars described this era as 'the age of global warming' (Nordhaus, 2007). Others claimed that climate change is 'the greatest and widest-ranging market failure ever seen' (Stern, 2007). Conceptually, climate change is a variation in the mean state of the climate persisting for an extended period (typically decades or longer) and resulting from anthropogenic greenhouse gas emissions (IPCC, 2007). More climate change is expected to take place in the form of increased global average air and ocean temperatures. The 
signals of climate change are ever manifested in enhanced frequency and heightened intensity of extreme weather conditions such as droughts, floods, storms, hurricanes, and heat waves. Warmer temperatures, changing precipitation patterns, sea level rise, and melting glaciers are broad signifiers of global warming.

From economist's perspective, climate is global public good and as such climate change is an externality. According to William Nordhaus of Yale University, climate change presents fundamental problem as it takes millions of firms, billions of people and trillions of decisions to face realistic carbon prices if their decisions about consumption, investment, and innovation are to be correct (Nordhaus, 2007). Hence the need for different interventions involving both market and non-market forces.

Another problem is that while "global-warming" explicitly indicates the global nature of climate change, vulnerability to climate change varies in time and space. Examples abound. A country that is prone to Monsoon climate such as Bangladesh is more susceptible to flooding than Ethiopia. A low-lying small island in the midst of oceans is more prone to rising sea levels than Zimbabwe. A community in a Canadian Arctic whose livelihood depends on hunting and fishing, faces different challenges to pastoralists in East Africa who are vulnerable to drought.

In other words, while all societies on earth are affected by climate change, its intensity and its severity vary from one location to another and across societies. Impacts are amplified for societies struggling to achieve poverty eradication and development (Adger, et al., 2003; Hope, 2009; Hassan, 2010).

\section{Development agendas of developing economies}

Developing countries including Ethiopia are already facing significant challenges of development such as poverty reduction, growth, and economic development. Climate change increases the intensity and focus of development challenges. Following on Rashid Hassen (2010:661) one would consider the issue of "double challenge of adapting to climate change while accelerating development in sub-Saharan Africa". In other words, the question arises as to how can Sub-Saharan African countries can accelerate economic growth and social development "necessary to reduce vulnerability and enhance their adaptive capacity to cope with the consequences of predicted unfavourable future climate'? Hassen opines that such an endeavour 'requires major investments and policy reforms to induce a needed radical transformation of the way development is currently pursued to a more climate-sensitive path of low carbon growth" (ibid).

It also means pursing pro-poor policies aimed at poverty reduction for further progress and human development to happen. A World Bank study stated that "peace and stability are not possible until poverty is alleviated" (Moreno-Dodson, 2005, p. vii). One way of reducing poverty is through economic growth measured in the growth of a country's GDP, over a period of time, often a year. Indeed, economic growth had been the focus of post-WWII development economics. 
In the decades that followed independence of many countries, the persistence of poverty despite economic growth altered the focus to poverty alleviation and fulfilment of basic needs. Since the 1970s, additional concerns appeared broadening wellbeing beyond minimalist measurements and well into the realm of the social and political indicators.

Questions were also raised not only about the measurement of wellbeing (Seers, 1979) but also about the meaning of development (Sen, 1981, 1991). Amartiya Sen's Development as Freedom and Capability Approach have expanded the dimensions of development discourse. Thus the concepts of capability, equity and sustainability came to be seen as both a good in themselves and an end (Chambers and Conway, 1991).

As a long term process, economic development subsumes economic growth (quantitative expansion of economy) and qualitative transformation of society and polity (Hameso, 2001). This process is affected by internal dynamism and global processes. Both global warming and global economic crises will have direct impact on economies.

Table 1: Important timelines in post-WWII development agendas

\begin{tabular}{|l|l|l|}
\hline Time & Event/Responsible agencies & Aim/Goals \\
\hline $1950 \mathrm{~s}-60 \mathrm{~s}$ & $\begin{array}{l}\text { Independence of countries } \\
\text { (Governments) }\end{array}$ & $\begin{array}{l}\text { Economic growth and development } \\
\text { models }\end{array}$ \\
\hline $1970 \mathrm{~s}$ & $\begin{array}{l}\text { Basic needs approach (Various } \\
\text { scholarly and policy circles) }\end{array}$ & $\begin{array}{l}\text { Provision of basic services (food, shelter, } \\
\text { clothing, etc...) }\end{array}$ \\
\hline $1980 \mathrm{~s}$ & $\begin{array}{l}\text { Structural adjustment programmes } \\
\text { (IMF, WB) }\end{array}$ & Macroeconomic and financial stability \\
\hline $2000 \mathrm{~s}$ & $\begin{array}{l}\text { Structural adjustment programmes } \\
\text { and poverty reduction programmes } \\
\text { (IMF and WB) }\end{array}$ & $\begin{array}{l}\text { Macroeconomic and financial stability } \\
\text { and poverty alleviation }\end{array}$ \\
\hline $2010 \mathrm{~s}$ & $\begin{array}{l}\text { Millennium Development Goals (UN) } \\
\text { Sustainable livelihoods approach } \\
\text { (Various scholarly and policy circles, } \\
\text { GOs, INGOs) }\end{array}$ & $\begin{array}{l}\text { Plan to achieve key development targets } \\
\text { by 2015 }\end{array}$ \\
$\begin{array}{l}\text { Develop capacities, assets, institutions for } \\
\text { sustainable livelihoods PLUS } \\
\text { mainstreaming climate change adaption } \\
\text { to development }\end{array}$ \\
\hline
\end{tabular}

\section{A brief history of environmental concerns on development}

Hardin's (1968) famous article, "The Tragedy of the Commons," described the degradation of shared resources under conditions of uncontrolled access. The argument is based on a communal land, where an individual villager reaps the benefit of each additional animal's grazing, while the whole village shares the cost of the reduction in available grass. As each villager pursues his or her own personal gain, the number of cattle rises until it eventually exceeds the carrying capacity of the commons. Hardin linked this metaphor to population growth as representing a tragedy of the commons (O’Neill 2001). 
Concerns about population and the use of natural resources for development continued well into the 1970s and thereafter. So did scholarly debate about the links between environment and development. The Brundtland Commission Report Our Common Future (United Nations, 1987) defined the concept of sustainable development as "development that meets the needs of the present without compromising the ability of future." Other scholars define sustainable development as the use of environmental resources in manners that produce positive outcomes for future generations. The issue relates to intergenerational justice, and it is the focus of much of the writings on the environment (Lundahl and Ndulu, 1996).

The goals of sustainable development including economic growth, environmental protection and equity are not without tension. A comprehensive strategy to address development and environmental tension through global partnership was agreed in June 1992 when the UN convened the Earth Summit in Rio de Janeiro in the form of Framework Convention on Climate Change (UNFCC). A few years later, the Kyoto conference of 1997 resulted in Kyoto Protocol (which was ratified in 2004). In 1998, the Intergovernmental Panel on Climate Change (IPCC) was formed to provide governments with a clear scientific view of what is happening to the world's climate.

In 2004, the UNDP published Climate Change Adaptation Policy Framework which recognised that adaptation occurs at different levels in society, including the local level (UNDP, 2004). This framework was instrumental for developing country governments to prepare their National Adaptation Plans of Action (NAPAs) (Adger et al., 2003).

Table 2: Important timelines in global climate change discourse and policy

\begin{tabular}{|l|l|l|}
\hline Time & Event & Aim/goal \\
\hline 1987 & $\begin{array}{l}\text { The Brundtland Commission } \\
\text { Report Our Common Future } \\
\text { (United Nations) }\end{array}$ & $\begin{array}{l}\text { Stated the overall objective of } \\
\text { sustainable development- } \\
\text { reconciling traditional development } \\
\text { objectives with environmental } \\
\text { ones: promoting harmony among } \\
\text { human beings and between } \\
\text { humanity and nature }\end{array}$ \\
\hline 1992 & $\begin{array}{l}\text { UN Conference on Environment } \\
\text { and Development, over 180 } \\
\text { countries signed, United Nations } \\
\text { Framework Convention on } \\
\text { Climate Change (UNFCCC) }\end{array}$ & $\begin{array}{l}\text { Agreement reached on the need for } \\
\text { serious action to reduce man-made } \\
\text { greenhouse-gas emissions }\end{array}$ \\
\hline 1997 & $\begin{array}{l}\text { Kyoto Protocol (ratified in 2004) } \\
\text { astablished a legally binding }\end{array}$ & $\begin{array}{l}\text { Estods } \\
\text { greenhouse-gas-emission targets } \\
\text { for industrialized countries to be } \\
\text { achieved in the target period 2008- } \\
\text { 2012 }\end{array}$ \\
\hline 1998 & Intergovernmental Panel on & Provide governments with a clear \\
\hline
\end{tabular}




\begin{tabular}{|l|l|l|}
\hline & $\begin{array}{l}\text { Climate Change (IPCC) was } \\
\text { formed }\end{array}$ & $\begin{array}{l}\text { scientific view of what is } \\
\text { happening to the world's climate }\end{array}$ \\
\hline 2004 & $\begin{array}{l}\text { UNDP's Climate Change } \\
\text { Adaptation Policy Framework }\end{array}$ & $\begin{array}{l}\text { Help developing country } \\
\text { governments to prepare their } \\
\text { National Adaptation Plans of } \\
\text { Action (NAPAs) }\end{array}$ \\
\hline 2007 & $\begin{array}{l}\text { Developing countries, including } \\
\text { Ethiopia produced their NAPA }\end{array}$ & $\begin{array}{l}\text { Specific adaptation options or } \\
\text { measures identified. }\end{array}$ \\
\hline 2012 & Durban Summit & $\begin{array}{l}\text { The formation of Durban Platform } \\
\text { (an Ad hoc group) to negotiate } \\
\text { legally binding emissions reduction } \\
\text { by 2015. But, any reductions won't } \\
\text { take effect before 2020. }\end{array}$ \\
\hline
\end{tabular}

For historical reasons, much of the literature in the area of climate-related risks (including policy and practice) dwelt on disaster risk management, often with short-term focus on relief efforts and poverty reduction programmes (Blaikie, et al., 1994; Siegel and Alwang, 1999; Brooks, 2003). More recent research moved towards resilience and sustainable livelihoods (IISD, 2003) and mainstreaming adaption to development (Huq, et al., 2004; Pouliotte, 2009). In the case of SSA, it is argued that development and adaptation challenges are inseparable (Hassan, 2010).

\section{Development challenges in the age of climate change}

The causal chain linking current economic behaviour to future economic consequences via climate change can be summarized as follows:

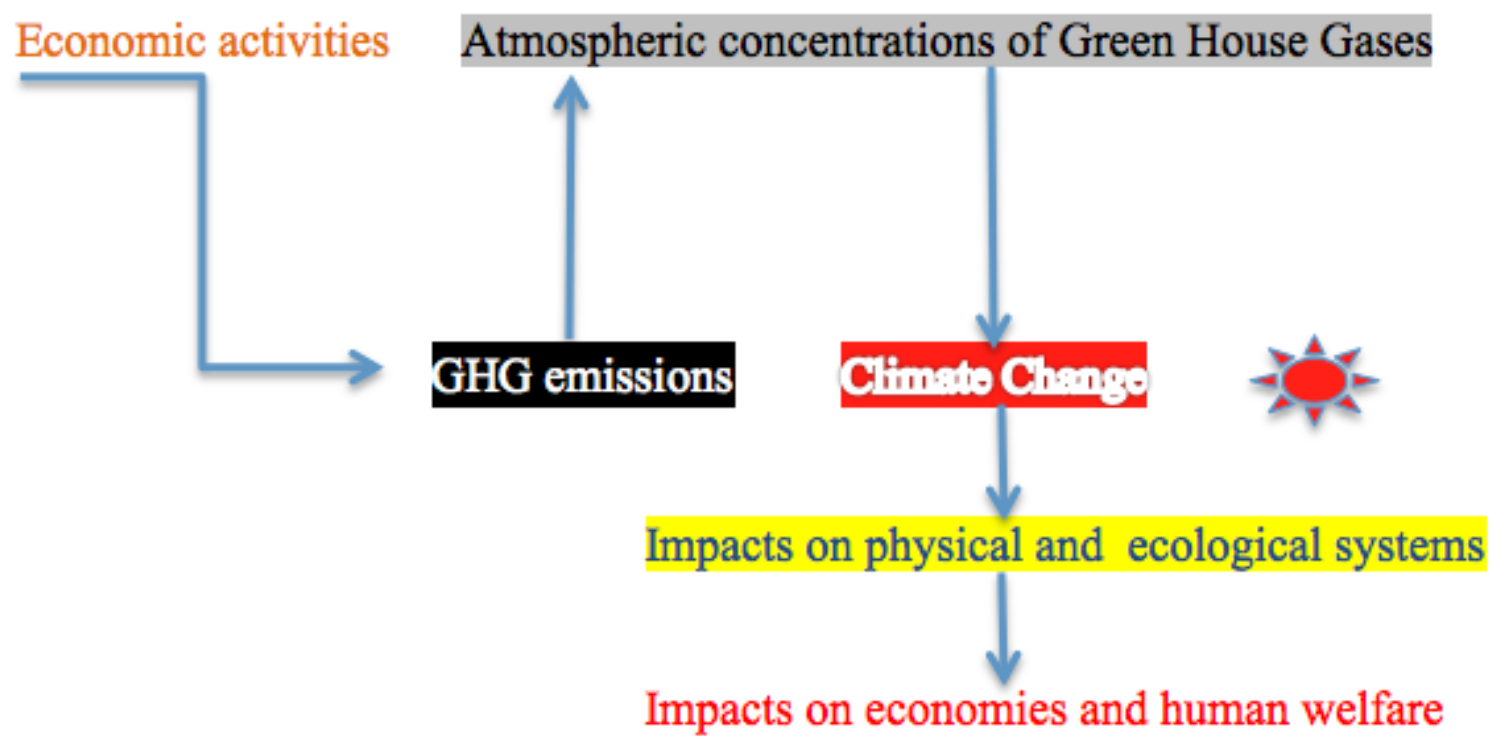

(adopted from Shalizi and Lecocq, 2009). 
It is expected that more climate change is on the way resulting from past, current, and future greenhouse gas emissions with its potential adverse impacts on socio-economic development of nations.

These adverse impacts of climate change pose unprecedented threat to the millions of people in developing countries (UNDP, 2007). These countries are particularly vulnerable due to their low adaptive capacity and high sensitivity of their socio-economic systems to climate variability and change (Adger, 2003; MoWRNMA, 2007; Morton, 2007).

More specifically, it deepens 'the risks faced by poor and vulnerable people in rural areas, particularly those involved in agriculture and other ecosystem-dependent livelihoods' (Davies, et al., 2009). Decreasing soil fertility, increasing deforestation, rising health problems compounded by inequitable access to resources render the achievement of livelihood security difficult.

It is also argued that "those regions where response [to climate change] is most urgently needed may also be where it is most constrained" (Smithers and Smit, 1997, p.130).

The impacts of climate change are exacerbated in countries where the dominant mode of livelihood is rain-fed smallholder agriculture such as Ethiopia.

The question then will be what can be done to address the problem of climate change. There are two responses: mitigation and adaptation.

Mitigation refers to actions and processes such as technological change or substitution that reduce greenhouse gas emissions and enhance sinks (IPCC, 2007; Sumi et al., 2010; Shalizi \& Lecocq, 2009). Adaptation, on the other hand, refers to adjustments in ecological-socio-economic systems in response to actual or expected climatic stimuli, their effects or impacts (Smit et al. 2000, p. 225).

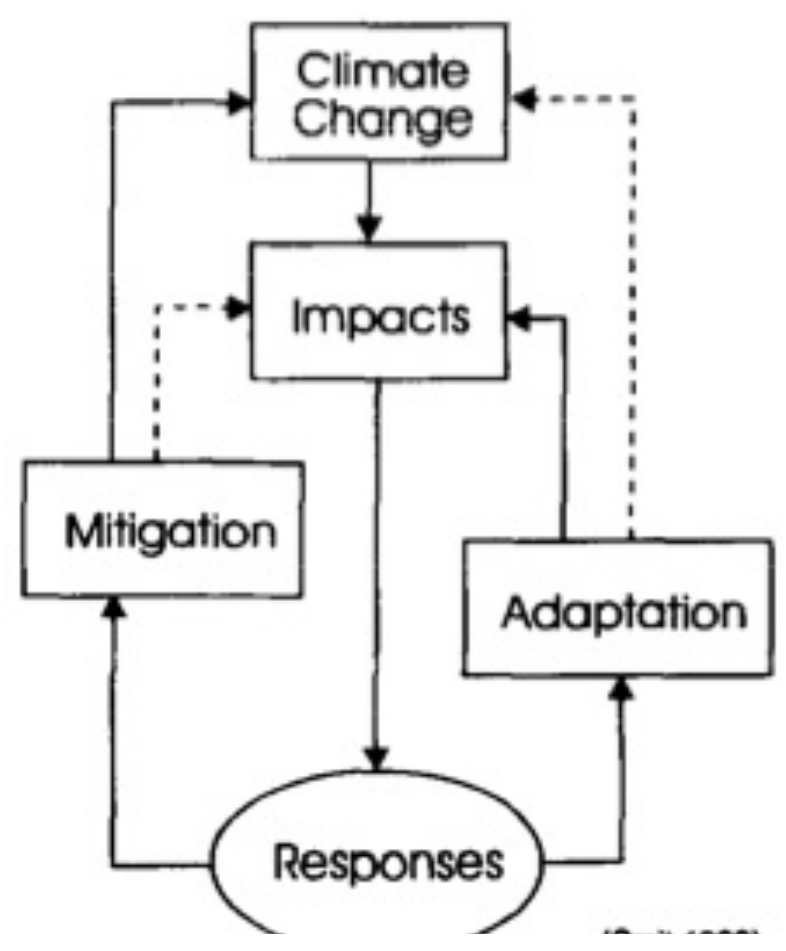

In terms of policy and research priority, further questions can be asked who needs to work on mitigation and who should focus on adaptation. One would argue that, with smaller contribution to climate change, developing countries face the effects nonetheless and they have to adapt to climate change in order to reduce their current and future vulnerability to climate change (Shalizi and Lecocq, 2009).

Figure 1: Responses to climate change, Smit, 1993. 
Some scholars note that while opportunities for mitigation could be limited to some countries, the need for adaptation is felt by all countries (Shalizi \& Lecocq, 2009). As climate change is expected to increase in the coming decades, and there is growing realisation that vulnerable countries and communities will be disproportionately adversely affected, much more attention is now paid to adaptation than was previously the case (Huq \& Reid, 2004, p.15).

It is acknowledged that even with a significant cut in emissions, damage will be large unless investment is made on adaptation with a view to develop adaptive capacities and reduce future vulnerability to climate change (Parry et al., 2008, p.69; IPCC, 2007).

Indeed both sides of the argument for adaptation and mitigation are valid but singlehanded reliance on one of them is misplaced. Recent literature (e.g. (van Vuurena, 2011) noted progress made to treat both mitigation and adaptation as supplemental to each other rather than mere trade-offs. For instance, the newly evolving mechanism of Nationally Appropriate Mitigation Actions (NAMAs) is expected to enable large-scale emission reductions in developing countries. Yet, as a policy instrument, this area is in a early stage of development (Wang-Helmreich, et al., 2011).

Eventually, either or both responses need to take into account local specificity and vulnerability to climate change.

\subsection{The case of Ethiopia}

One of the specific developing countries affected by climate change is Ethiopia. Climate data for fifty years (1951-2006) shows that temperature has increased by $0.37^{0} \mathrm{c}$ every ten years (MoWRNMA, 2007). The increase had direct impacts on different sectors and areas in the country.

The country already faces several environmental problems ranging from land degradation, soil erosion, deforestation, loss of biodiversity, to desertification (Deressa, 2010). The most pronounced problems are recurrent drought, floods, famine and lack of food security.

High vulnerability to climatic risks is linked to dependence on climate-sensitive livelihoods, low economic development, low service coverage, underdeveloped water resources, inadequate road infrastructure, low adaptive capacity, and weak institutions. The economy is based on largely rain-fed agriculture which contributes $45 \%$ of GDP, $60 \%$ of foreign exchange earnings, $80 \%$ of employment (CSA, 2007; MoFED, 2010).

Dependence on undiversified livelihoods based on rain-fed agriculture means that production is sensitive to fluctuations in rainfall. Such dependence remains the source of vulnerability to poverty, food insecurity and their consequences including malnutrition 
and recurrent famines (Conway et al. 2011; Devereux, 2000; Devereux and Guenther, 2007, p.2).

In recognition of the problems of climate change, an adaptation plan and a green economy strategies are proposed. For example, the draft policy document on adaptation to climate change states:

"Ethiopia's direct and disproportionately high dependence on natural resources and climate sensitive livelihoods coupled with the prevalence of rampant poverty places the country in a most vulnerable position. According to the National Meteorological Agency, agriculture, water and range resources, biodiversity and human health are vulnerable to climate variability and change, with huge social and economic impacts." (EPA, 2011)

\subsection{The case of Sidama}

Within the same framework, Sidama Zone and SNNPR region have been experiencing climate change. In the last decade, average temperature of the SNNPR region had risen by $0.4{ }^{\circ} \mathrm{c}$ (NREPA, 2012) above the national $0.37^{\circ} \mathrm{c}$ (MoWRNMA, 2007). This shows the seriousness of the problem in the region.

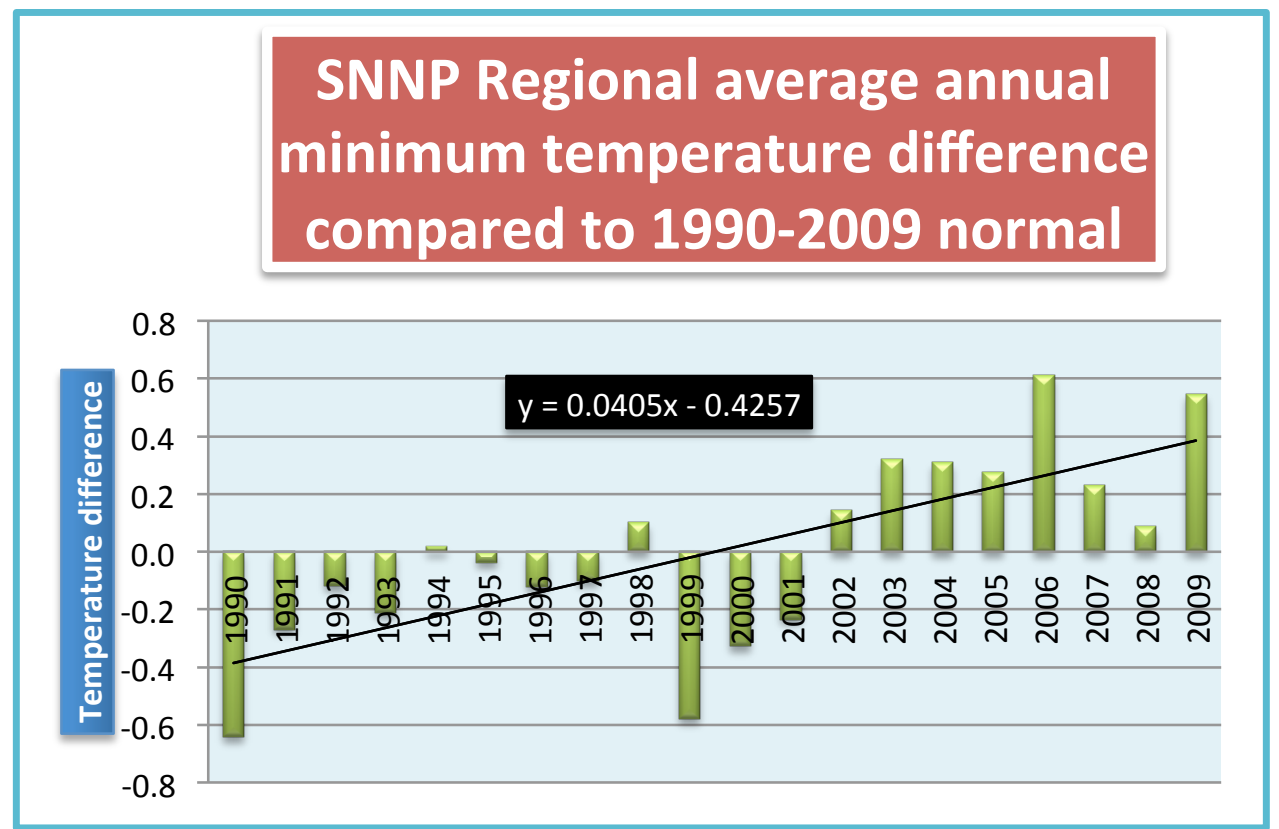

(Source: NREPA, 2012)

The above characteristics apply to the Sidama Zone. According to official statistics (CSA, 2007), the Sidama zone has a total population of 2,954,136. It has an area of 6,538 square kilometres with a population density of 452 per square kilometres (one of the highest in the country). Rural residents account for over $94 \%$ of the population. A recent research involving 1094 households from highland and midland ecological zones, 
showed that about $75 \%$ respondents reported to be moderately and severely food insecure (Regassa and Stoecker, 2011:1).

In terms of climate change related research, current knowledge and understanding of vulnerability and adaptation by communities in Sidama is weak or non-existent. The economy of these communities is largely based on smallholder farming dependent on indigenous enset/wesse and coffee. In a coffee producing Uganda, it is argued that a predicted increase in temperature by an average of $2^{\circ} \mathrm{C}$, would drastically reduce production of Robusta coffee, Uganda's major export crop therefore limiting it to highlands (Ben, 2005). Similar scenario could as well apply to Sidama case where coffee production could cease in the midlands and move to the highlands with serious consequences on the livelihoods of millions here and beyond.

The most severely affected areas in the Zone are semi-arid and dry areas such as Boricha, Loka Abaya, Hawassa Zuria districts, to name a few. These areas experienced higher temperature and receive less rainfall. The same areas have been subject to several interventions including the PSNP or Safety Net programmes whose results have yet to be proven from sustainable development point of view.

The following are most recent pictures showing the extent of environmental and developmental challenges facing the Sidama Zone.

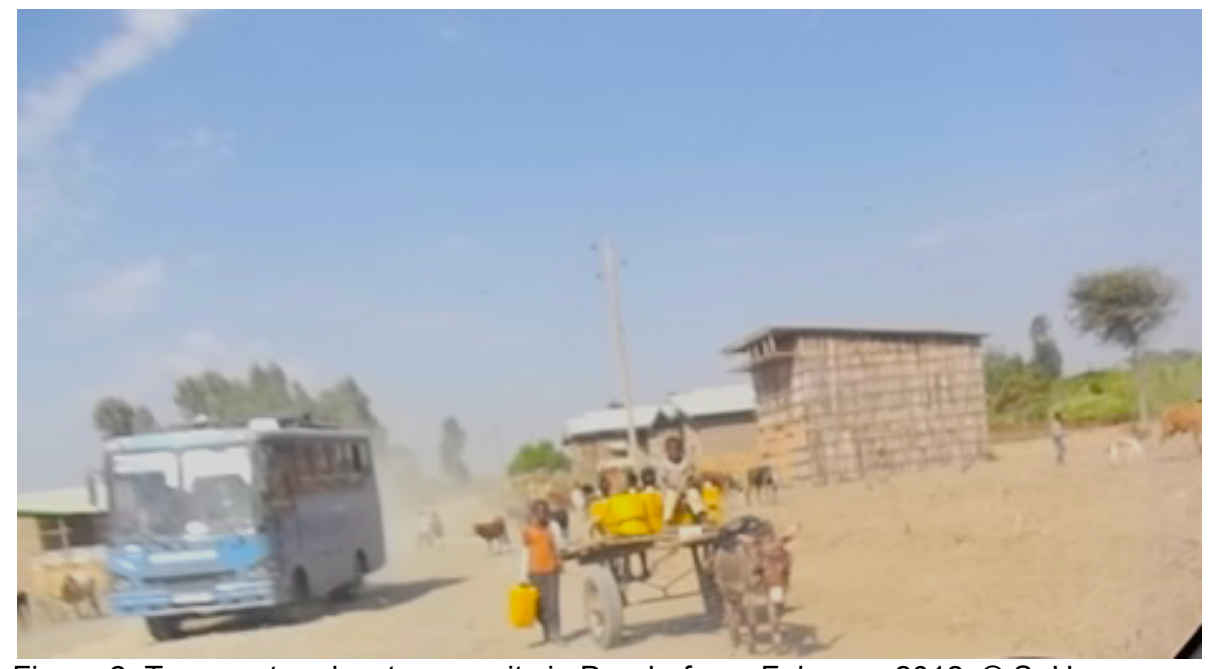

Figure 2: Transport and water scarcity in Dorebafano, February 2012 @ S. Hameso 


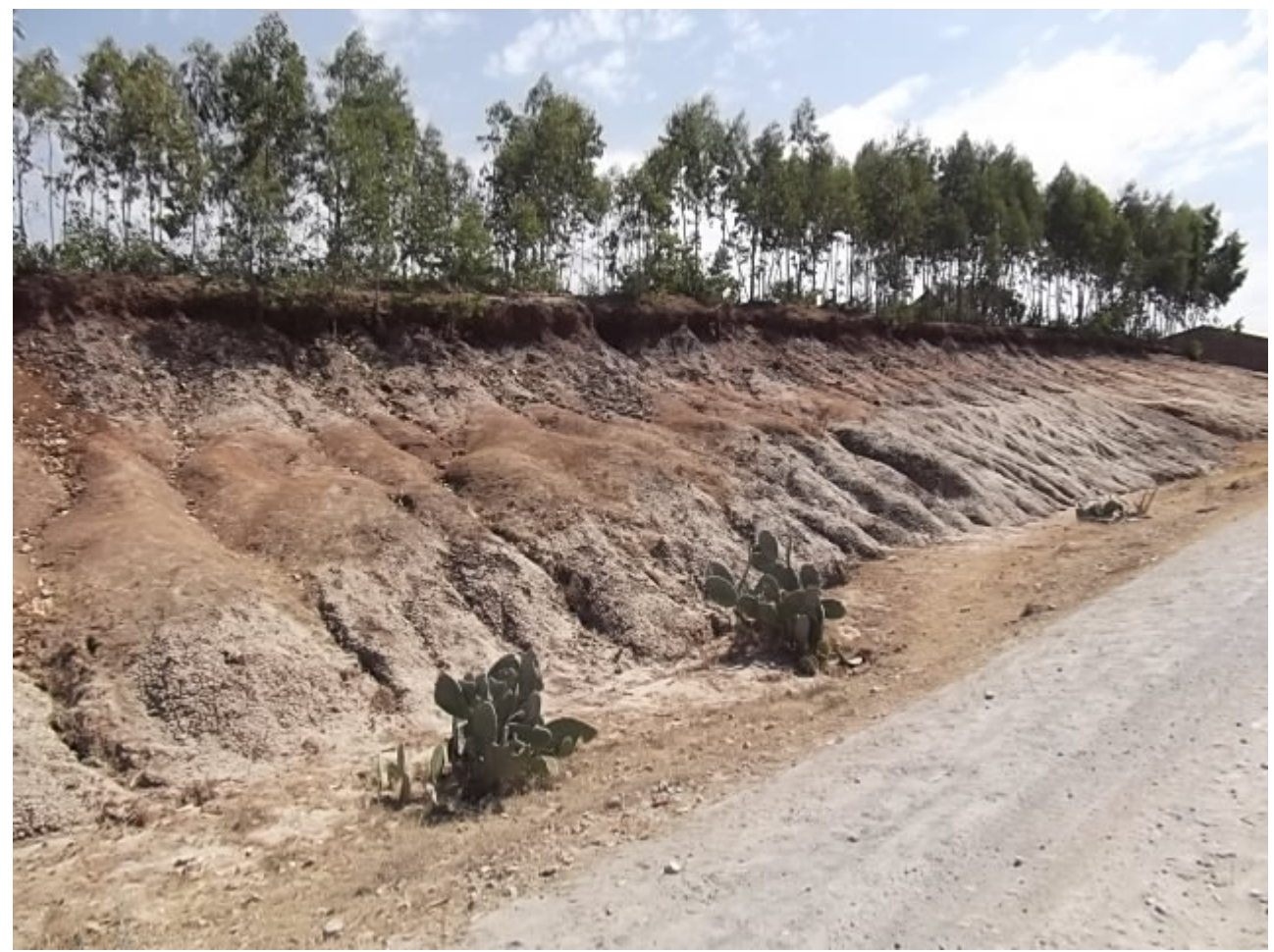

Figure 3: Roadside soil erosion, Boricha district, February 2012 @ S. Hameso

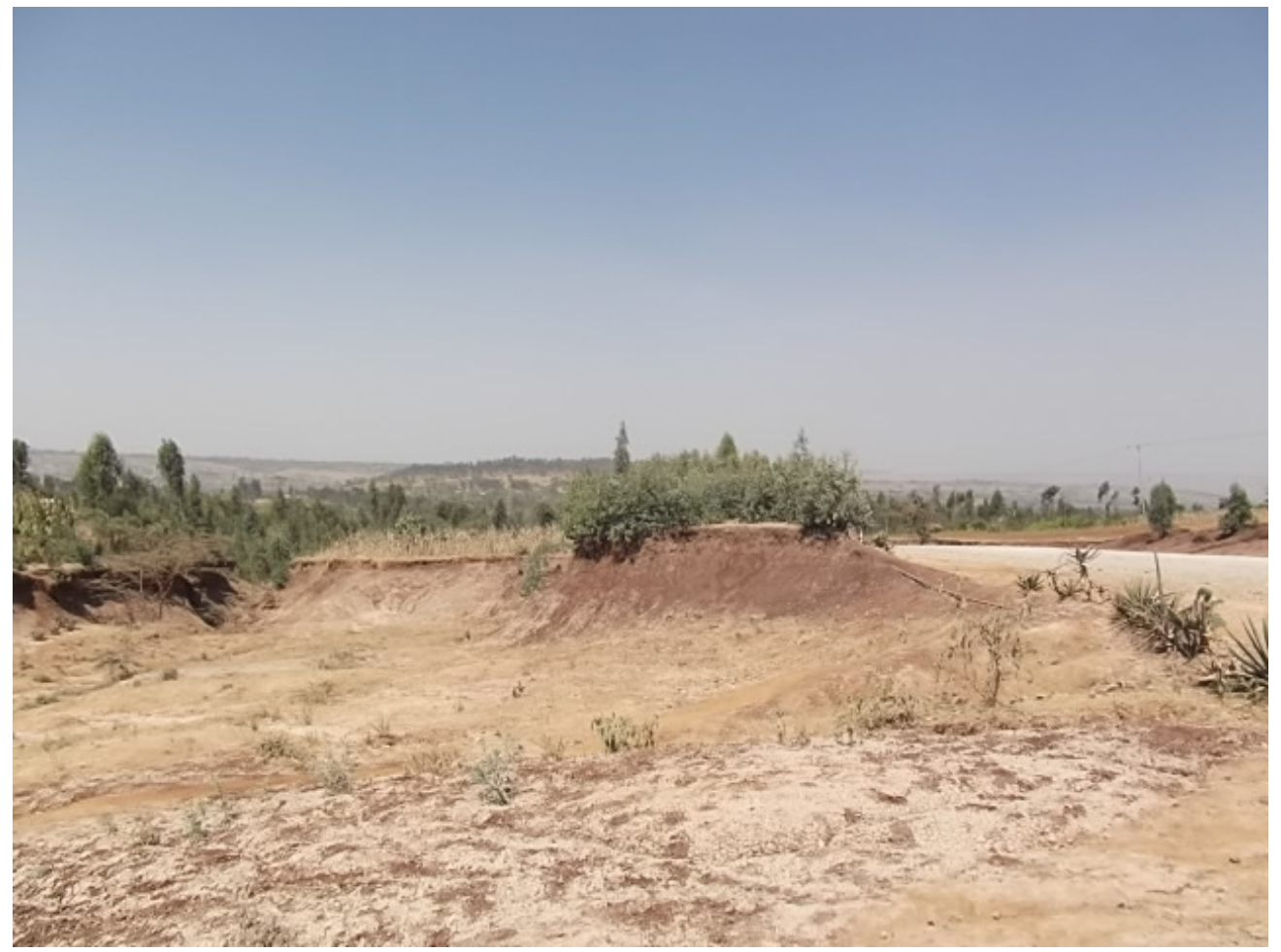

Figure 4: Landslides and soil erosion, Hawassa Zuria, February 2012 @ S. Hameso 


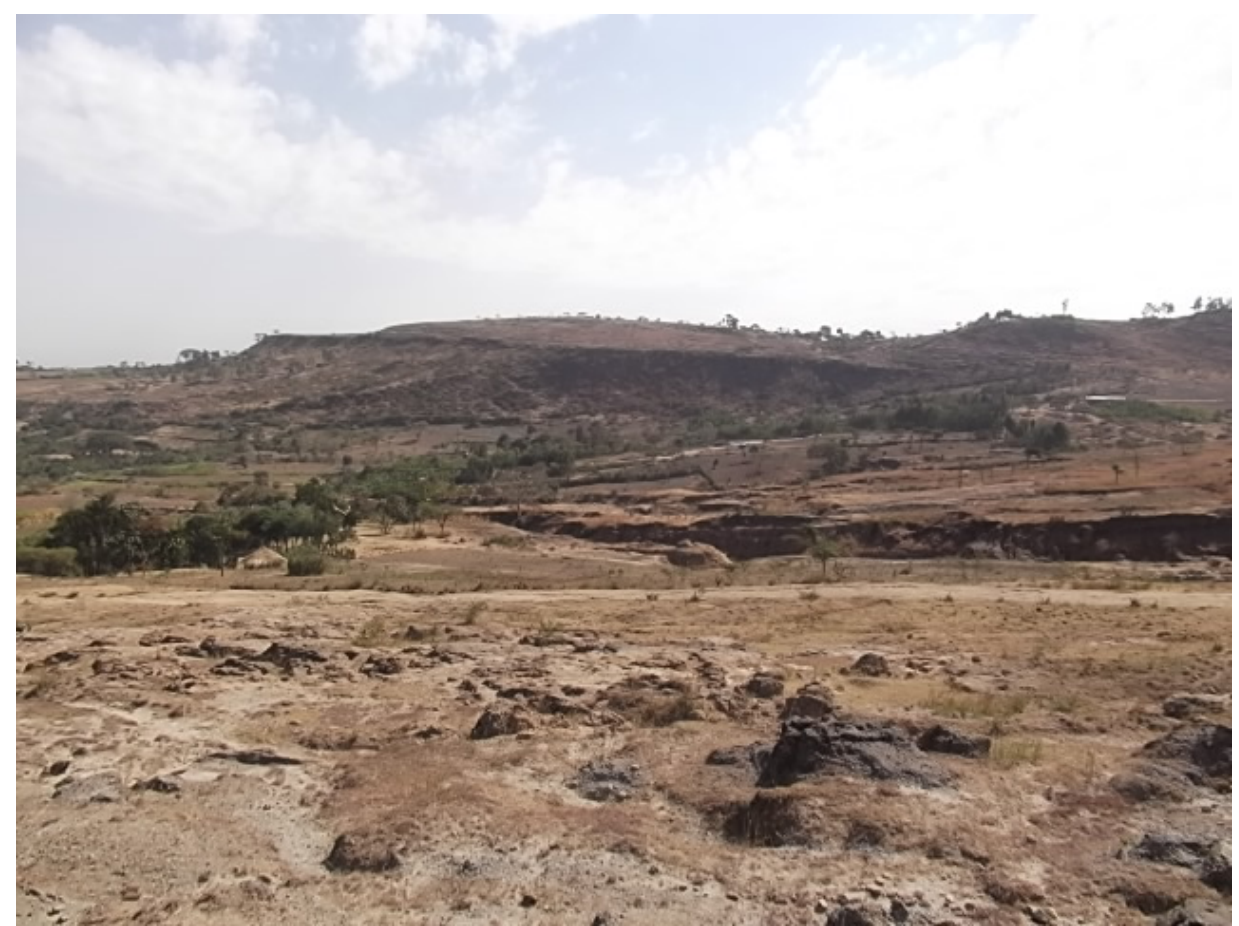

Figure 5: Land degradation, Boricha, February 2012 @ S. Hameso

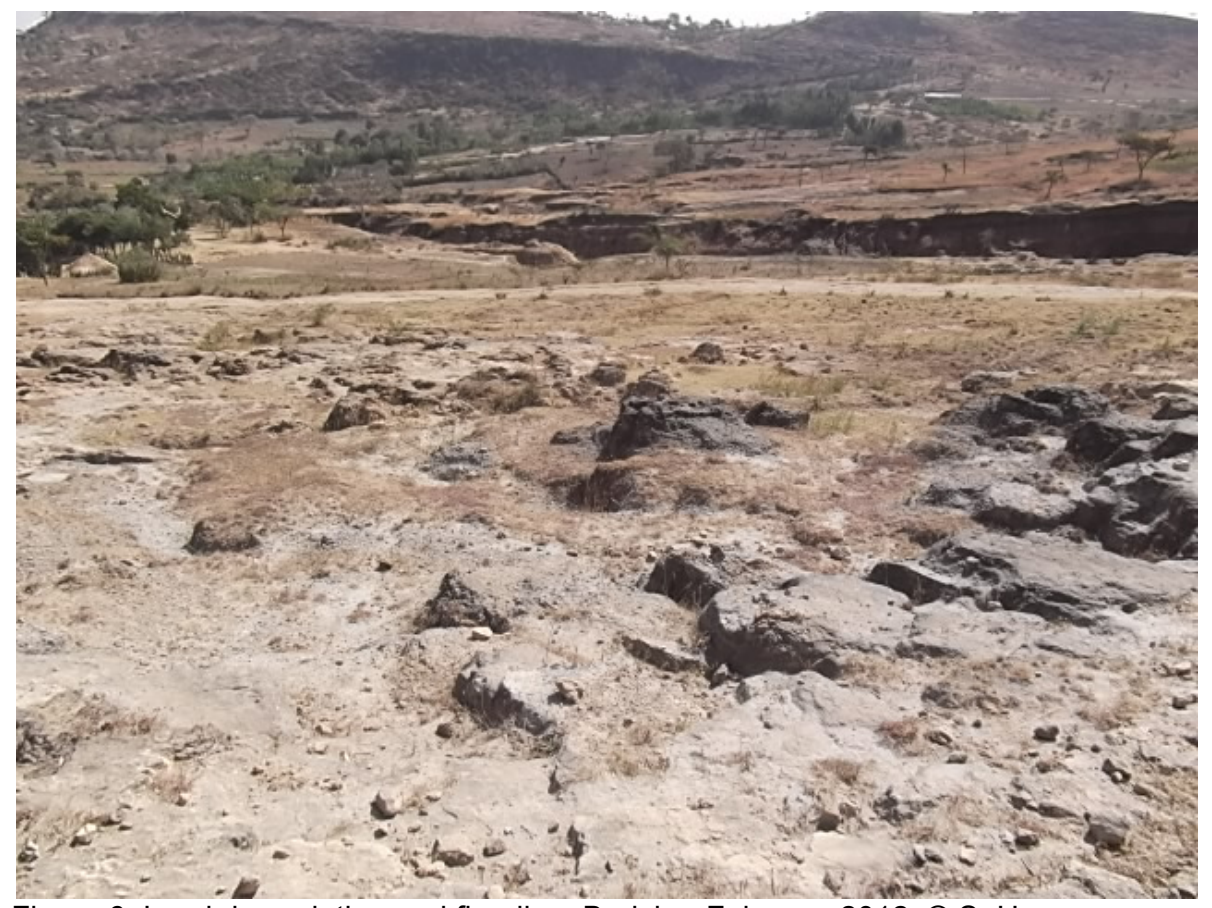

Figure 6: Land degradation and flooding, Boricha, February 2012 @ S. Hameso 


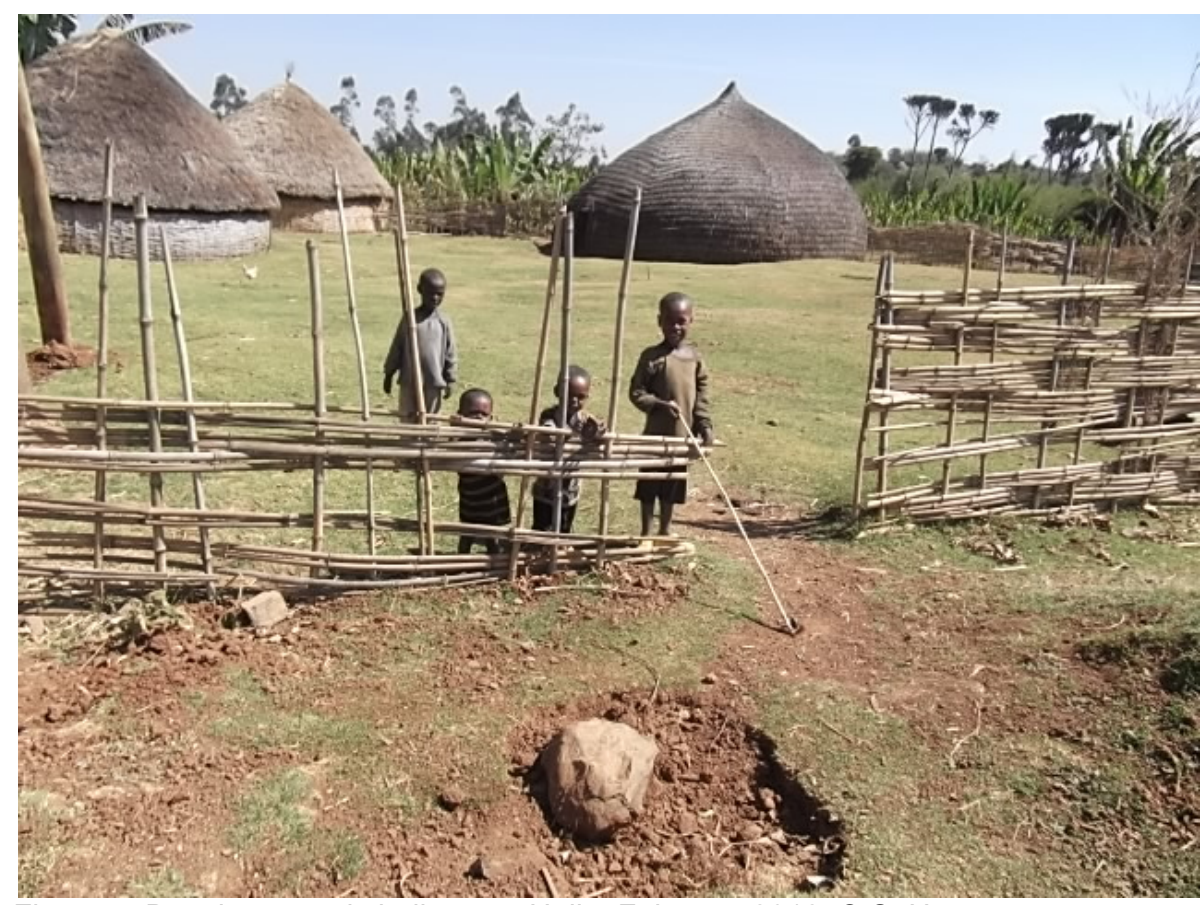

Figure 7: Developmental challenges, Hulla, February 2012 @ S. Hameso 


\subsection{Development constraints and opportunities in the age of climate change}

The key problems developing countries face are as follows:

- Underdeveloped infrastructure, markets and institutions

- Poverty

- Overpopulation and natural resource degradation

- Globalization

- Climate change

The first four challenges are broadly covered in the literature and they are selfexplanatory. The focus here is challenges associated with climate change. It is rightly argued that as we understand more about the impacts of climate change, adapting to these impacts has grown from a minor environmental concern to a major challenge for human development, and a crucial element in eradicating poverty and achieving the Millennium Development Goals" (Davies, et al., 2008).

An important challenge with climate change is how to enhance adaptive capacity through economic growth. In the case of SSA, one would concur with Hassen (2010:661) when he wrote:

To achieve faster growth and development ... SSA requires more aggressive efforts and major investments in many sectors that would require much higher levels of energy use and emissions and increase the pressures on the already stressed land, water and other natural resources of the region. Development and adaptation challenges for SSA are accordingly inseparable.

Apart from addressing these challenges, it is also vital to explore possible opportunities for development within the constraints of contemporary era.

\section{Possible development opportunities}

Many developing nations are "late-comers" starting from low economic base. They would require less of a cost to adjust to carbon neutral growth path than those countries whose economic structures are intricately and intimately tied to fossil fuel combustion. Thus they can pursue a no-regrets approach to adaptation to climate change. Potentials also exist for innovative technologies for environment friendly inventions. These countries can promote alternative and renewable sources of energy including hydropower/dams.

Developing economies also have large pool of human power/resources to undertake green economy/activities, such as planning trees, basin and watershed projects.

Today, there are a wide array of means to increase environmental awareness, including the media, education, social networks and institutions, etc. The area of opportunities for progress needs increased research by academic and research institutions. 
More importantly, developing countries can undertake both mitigation and adaptation measures with the funding support from developed countries. For example, the idea of 'carbon offsets' is potentially large supported through the medium of the Global Environment Facility (GEF) (Lundahl and Ndulu, 1996).

\section{Conclusions and recommendations}

The field of research into the study of the vulnerability of human and natural systems to climate change and variability is a relatively new bringing together experts from a wide range of fields, including climate science, development studies, disaster management, health, social science, economics and policy development, to name but a few (Brooks, 2003, p.1). Such a multi-disciplinary approach combined with multi-agency co-operation is vital to address complex problems related to climate change and development.

More importantly, there is a broad recognition that climate change poses unprecedented threat to the livelihood of millions of people who depend on small-scale agriculture. Africa is highly vulnerable to future climate change and Ethiopia is often cited as one of the most extreme examples. In these circumstances, climate change adaptation should be mainstreamed in development policy, taking into consideration local vulnerability and adaptation to climate change.

Being a global problem, climate change should be tackled by all. Any blame-game and business-as-usual approaches do not help face the challenges of climate change. Instead of attributing the problem to any part of the world all need to cooperate on mitigation and adaptation. This is the understanding reached at Durban Summit, where countries, advanced and developing agreed on some actions towards mitigation and adaptation. While none of the international negotiations pass without challenge, the cost of inaction is huge both for the current and the future generations.

Finally, the need for more research and awareness raising efforts is obvious. Here the role of higher education institutions (by incorporating climate change education into their curricula), research establishments and the public media is paramount. Public institutions such as the National Metrological Agency need to establish robust climate forecasting with investment in local stations. For informed policy is half-way to solve a challenge. 


\section{References}

Adger, N. Huq, S., Brown, K., Conway, D. Hulme, M., (2003) 'Adaptation to climate change in the developing world', Progress in Development Studies 3(3), pp.179-195.

Ben, T. (2005) A content analysis reports on climate change impacts, vulnerability and adaptation in Uganda. [Online]. Available at: http://pubs.iied.org/pdfs/10011IIED.pdf (Accessed on 7 September 2011)

Blaikie, P., Cannon, T., Davis, I., and Wisner, B. (1994) At risk: Natural hazards, people's vulnerability, and disasters. London: Routledge.

Brooks, N. (2003) Vulnerability, risk and adaptation: A conceptual framework. Tyndall Centre for Climate Change Research Working Paper 38. November.

CSA (Central Statistical Authority) (2007) Tables: SNNP Region. [Online]. Available at: http://www.csa.gov.et/index.php? option=com_rubberdoc\&view= doc\&id=273\&format=ra \&Itemid=521. (Accessed: 31 July 2011).

Chambers, R. and Conway, G. (1991) 'Sustainable rural livelihoods: practical concepts for the $21^{\text {st }}$ century', IDS Discussion Paper 296, Brighton: IDS.

Conway, D., Lisa, E., Schipperc, F. (2011) 'Adaptation to climate change in Africa: challenges and opportunities identified from Ethiopia', Global Environmental Change, 21(1), pp.227-237.

Davies, M., Leavy, J., Mitchell, T. and Tanner, T. (2008) Social protection and climate change adaptation: briefing note for Expert Group to the Commission on Climate

Change and Development, Ministry for Foreign Affairs, Sweden, Institute of Development Studies.

Davies, S. (1993) 'Are coping strategies a cop-out?', IDS Bulletin 24 (4), 60.

Devereux, S. (2000) Food insecurity in Ethiopia. A discussion paper for DFID, Sussex: Institute for Development Studies, pp.1-18

Devereux, S. and Guenther, B. (2007) Social protection and agriculture in Ethiopia. Institute of Development Studies, University of Sussex. 30 November.

Environmental Protection Agency, EPA, (2011) Ethiopia's programme of adaptation to climate change, first draft, Addis Ababa: EPA.

Hameso, S. (2001) Development, state and society: Theories and practice in contemporary Africa. New York: Authors Choice Press.

Hardin, G., 1968, The tragedy of the commons, Science, 162:1243-1248. 
Hassan, R. (2010) 'The double challenge of adapting to climate change while accelerating development in sub-Saharan Africa', Environment and Development Economics, 15, pp. 661-685.

Hope, K. R., (2009) 'Climate change and poverty in Africa', International Journal of Sustainable Development \& World Ecology, 16(6), pp.451-461

Huq, S. and Reid, H. (2004) 'Mainstreaming adaptation in development', Institute for Development Studies Bulletin, 35(3), pp.15-21.

Giddens, A. (2009) The politics of climate change. Malden: Polity.

IISD (International Institute for Sustainable Development) (2003) Livelihoods and climate change: A conceptual framework paper prepared by the task force on climate change, vulnerable communities and adaptation, Winnipeg: International Institute for Sustainable Development.

IPCC (2007) Parry, M.L. (eds). Climate Change 2007: Impacts, Adaptation and Vulnerability. Contribution of Working Group II to the Fourth Assessment Report of the Intergovernmental Panel on Climate Change. Cambridge University Press: Cambridge, pp. 273-313

Lundahl, M. and Ndulu, B.J. (eds), (1996). New directions in development economics: Growth, environmental concerns and government in the 1990s. Routledge: London

Ministry of Finance and Economic Development (MoFED) (2010) Ethiopia: Building on Progress: A plan for accelerated and sustained development to end poverty (PASDEP) (2005/06-2009/10), Addis Ababa: MoFED.

Ministry of Water Resources and National Meteorological Agency (MoWRNMA) (2007) Climate Change National Adaptation Programme of Action (NAPA) of Ethiopia, Addis Ababa: MoWRNMA.

Moreno-Dodson, B. (ed). (2005) Reducing Poverty on a Global Scale: Learning and Innovating for Development - Findings from the Shanghai Global Learning Initiative, Washington DC: The World Bank.

Morton, J. (2007) 'The impact of climate change on smallholder and subsistence agriculture', $P N A S, 104(50)$, pp. 19680-19685. [Online]. Available at:

http://www.pnas.org/content/ 104/50/19680.full.pdf (Accessed: 23 May 2011).

Natural Resources and Environmental Protection Agency (2012) Climate change adaptation guideline - Draft Document, Hawassa: SNNPR, NREPA. 
Nordhaus, W. (2007). The challenge of global warming: economic models and environmental policy, New Haven. [Online]. Available at:

http://nordhaus.econ.yale.edu/dice_mss_072407_all.pdf (Accessed: 30 August 2011).

O’Neill, B. (2001). Population and climate change. Cambridge: Cambridge University Press.

Pouliotte, J., Smit. B., and Westerhoff, L. (2009) 'Adaptation and development:

livelihoods and climate change in Subarnabad, Bangladesh'. Climate and Development, 1, pp.31-46.

Regassa, N and Stoecker, B. (2011) Household food insecurity and hunger among households in Sidama district, southern Ethiopia, Public Health Nutrition.

doi:10.1017/S1368980011003119. Pp.1-8

Seers, D., (1979) 'The Meaning of development', in Seers, Nafziger, Cruise O'Brien, and Bernstein, pp. 9-30.

Sen, A. (1999) Development as freedom, Oxford University Press, Oxford (1999).

Sen, A. (1981) Poverty and famines: an essay on entitlement and deprivation Oxford: Oxford University Press

Shalizi, Z. and Lecocq, F. (2009) 'To mitigate or to adapt: Is that the question? Observations on an appropriate response to the climate change challenge to development strategies', The World Bank Research Observer. Oxford: Oxford University Press.

Siegel, P., and Alwang, J. (1999) An asset-based approach to social risk management: A conceptual framework, Social Protection Discussion Papers 21324, The World Bank, Washington, D.C.

Smit, B., Burton, I., Klein, R., and Wandel, J. (2000) 'An anatomy of adaptation to climate change and variability’, Climatic Change, 45, pp.223-251.

Smit, B. (ed.) 1993. Adaptation to climatic variability and change. Guelph: Environment Canada.

Smithers, J. and Smit, B. (1997). Human adaptation to climatic variability and change, Global Environmental Change, Vol. 7. No. 2. pp. 129-146.

Stern, N. (2007) The economics of climate change: The Stern review. Cambridge: Cambridge University Press.

Sumi, A., Fukushi,K., and Hiramatsu, A. (eds) (2010) Adaptation and mitigation strategies for climate change. Tokyo: Springer. 
UNDP (2007) Human development report 2007/08. Fighting climate change: solidarity in a divided world. Cambridge: United Nations Development Programme.

UNDP (2004) Adaptation policy frameworks for climate change: Developing strategies, policies and measures. New York: Cambridge University Press

van Vuurena, et al. (2011) 'The use of scenarios as the basis for combined assessment of climate change mitigation and adaptation', Global Environmental Change, 21(2), pp. 575-591.

Wang-Helmreich, H., Sterk, W., Wehnert, T., and Arens, C. (2011) 'Current developments in pilot Nationally Appropriate Mitigation Actions of developing countries (NAMAs)', JIKO Policy Paper 01/2011.

World Bank (2010) World development report: Development and climate change, Washington, DC.: World Bank 


\section{Appendix}

A concept map relating to climate change: Development in the era of Climate Change

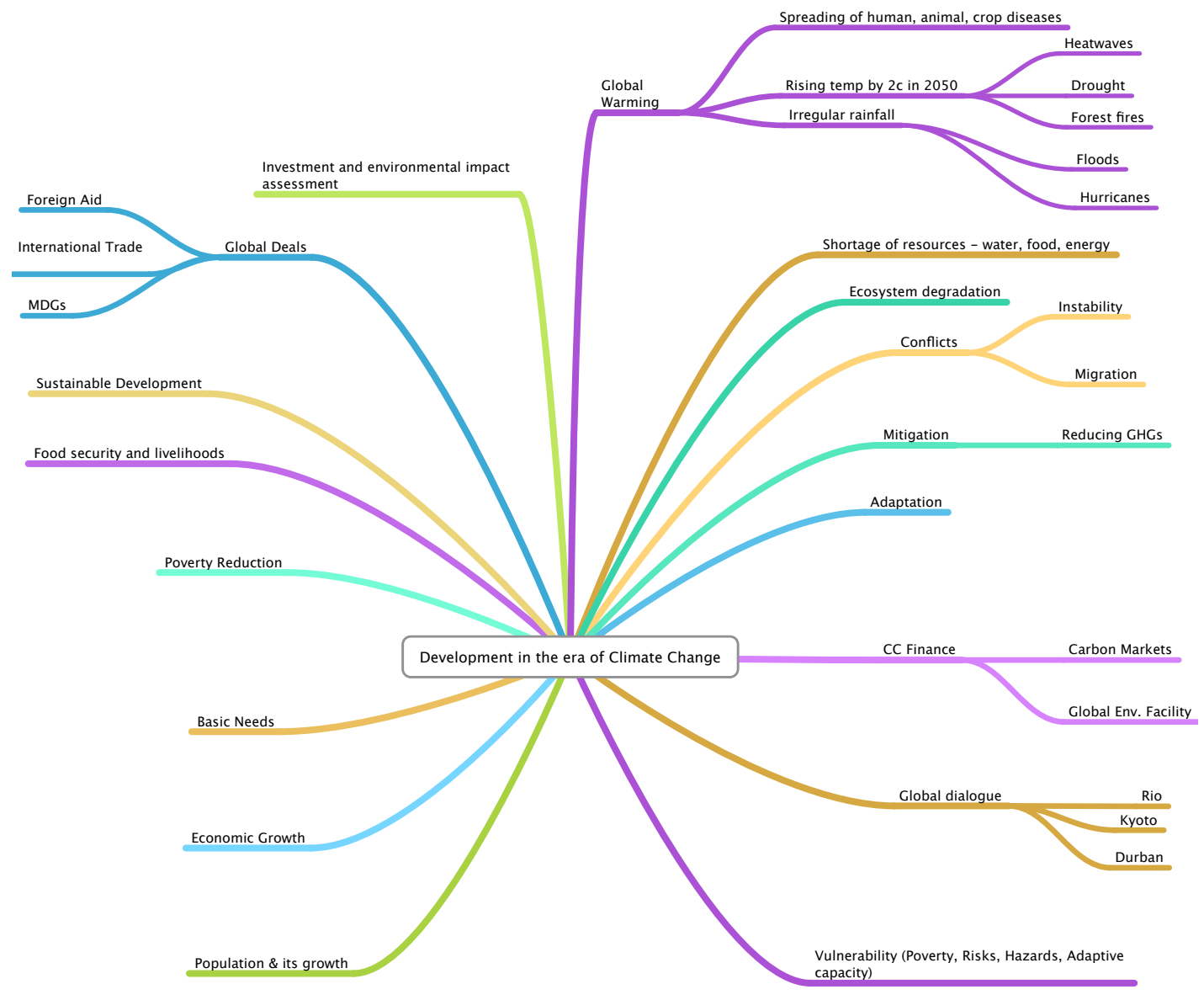

